\title{
Full day school program in forming environmental care character of junior high school students
}

\author{
T. Uda*, E. Karliani, Sakman \& Dotrimensi \\ Palangka Raya University, Palangka Raya, Indonesia
}

\begin{abstract}
This study aimed to analyze and evaluate the implementation of full-day schools with the character of environment care. This study was a qualitative descriptive, that was analyzed through descriptive techniques, specifically reduction, display, presentation, and conclusion. The results are: (1) readiness of facilities and infrastructure is classrooms, parking, sports facilities, worship facilities, student playground, gardens or parks, canteens; (2) programs run at school environment care characters are class pickets, musa (picking the trash), jumsih (Friday cleaning), hydroponic parks, outdoor activities, reducing the use of plastic waste, and class cleanliness competitions; (3) the implementation of the full-day school has allowed students to feel happy because they can interact longer with their friends and can do many positive activities such as being involved in watering plants, caring for their hygiene. Parents agree because it can increase the formation of character, especially religious and social character.
\end{abstract}

Keywords: full day school, environment care, character

\section{INTRODUCTION}

The environment care character is one of the 18 characters developed by the Ministry of Education and Culture. It is related to how students have an understanding, attitude, and behavior that loves to take part in protecting the environment around their homes for their survival and future generations. Every human life depends on the environment. A clean, healthy environment is the right of every. There are several examples of students' behaviors that do not reflect their concern for the environment, one example is the behavior of littering, damaging the green plants of the school, polluting the walls of the school, and lack of caring for classrooms and school's cleanliness in general. Palangka Raya City is one of the cities which has local characteristics which are located in river basins and peat swamp areas. Environmental care is needed to prevent disasters caused by human activities on the environment, one of which is forest fires and floods (Suparwadi, 2013; Andikurrahman, 2012).

Several characters have been studied in previous studies as the result of full-day school activities. They have produced findings that the implementation of full-day school activities will improve students' religious character, increase learning motivation, and improve students' critical thinking skills. Meanwhile, no research examines the implementation of full-day school about the environmental care character for State Junior High School/MTs students. Considering that one of the problems in Palangka Raya City is related to the environment, the results of research that become the community's concern for the environment in Palangka Raya City are about waste management.

The behavior of the people of Palangka Raya City in disposing of garbage is not good and orderly. For example, the garbage disposal schedule that has been set by the City Government through the cleanliness and city planning service has not been implemented properly, there is still

${ }^{*}$ Corresponding Author 
the behavior of the people who throw garbage not at the garbage bin but into rivers and forests that are around the residents' settlements, there are still many forests which is near the highway which is used as a landfill so that garbage is scattered into the streets (Suparwadi, 2013; Sutarmin, 2014; Alhamuddin \& Buchori, 2016).

This study needs to be done to analyze the implementation of a full-day school program, and provide alternative solutions to problem-solving by developing a model of full-day school activity programs to form the character of environmental care. The question in this study how the implementation of full-day school can form the character of caring for the environment if the learning activities at school provide understanding, awareness, and habitual behavior to students to love the environment and have care (respect) for the environment?

\section{METHODS}

This study is a qualitative descriptive study to analyze and evaluate full-day school programs informing the environmental care character of junior high school students in Palangka Raya City. The stages of the research will be carried out and elaborated as follows: (1) the research team developed a research instrument based on the indicators of the full-day school program informing the environmental care character of junior high school students in Palangka Raya City. The indicators of implementing a full-day school program include readiness of school infrastructure facilities in the implementation of full-day school programs to form the character of environment care (checklist list); activities program in implementing full-day school to form the character of environment care; human resources readiness (principals, teachers, non-academic staffs) in implementing full-day school programs to form the character of environment care; readiness of the students in implementing full-day school programs to form the character of environment care; parental support in implementing full-day school programs to form the character of environment care. (2) Gathering the data in the schools that have implemented a full-day school program with techniques: surveys, interviews, observations, and documentation. (3) The team conducted data analysis to conclude the full-day school program to form the environmental care character of State Junior High School/MTs students in Palangka Raya city following the data collection techniques. The results of the study were analyzed using qualitative descriptive data analysis. (4) Based on the results of the field data, the team compiled a report related to research and formulated several full-day school program activities to be implemented by the school.

To find out the successful implementation of the full-day school program, it was carried out in the form of an interview guide in the form of an open question list for the school principal, teachers, students' parents, and the students themselves related to environmental care character indicators, specifically: (1) always maintain environmental preservation, (2) do not take cut down or uproot vegetation along the way, (3) do not scribble, write inscriptions on trees, stones, roads or walls, (4) always throw trash in its place, (5) do not burn rubbish around housing, (6) carry out environmental cleaning activities, (7) collect used goods, and (8) clean up trash that clogs waterways.

\section{RESULTS AND DISCUSSION}

The research team determined the research locations were in SMPN 1 Palangka Raya, SMPN 2 Palangka Raya, SMP Christian Golden School, SMP IT Hasanka. The selection of research locations was based on the representation of the public junior high school based on the observations of the researchers having readiness in conducting a full day school research is as follows:

\subsection{Readiness of the school infrastructure facilities in implementing full-day school programs to form the character of environment care}

SMPN 1 Palangka Raya has a school corner for subjects, especially Pancasila and Civic Education (PPKn) and Bahasa Indonesia, for the future the school will develop a school corner for other 
subjects. The school corner is designed to strengthen the achievement of subject competencies in addition to the activities carried out in the classroom. In the corner of the school students can learn while breathing fresh air, outside the room by learning everything around them. In addition, SMPN 1 Palangka Raya also has a clean canteen that provides food for students, has a school garden, hasKa trash can, hygiene advice in the classroom and outside the classroom, and has live plants in the classroom.

SMP IT Hasanka has a distinguished student rest area for both boys and girls which has a clean canteen that provides food for the students, has a school park, has trash cans, sanitary facilities in the classroom and outside the classroom, and have live plants in the classroom. At SMP Golden Christian School, the school provides a school canteen, which provides healthy food catering for students. They can choose the food they want according to the menus provided. During breaks, students are required to eat in the dining room, not in the classroom, and they can play in the park and school environment. They must not be discharged from school when it is still school hours. SMPN 2 Palangka Raya already has a green park and a school garden, a sports field, has a clean canteen that provides food

The readiness of school facilities and infrastructure to support the implementation of full school can be run well. The availability of school facilities and infrastructures such as classrooms, parking lots, sports facilities, worship facilities, student playgrounds, gardens or school parks, a canteen that adequately provides the food needs of students, will provide space and a comfortable feeling while students carry out full-day school activities in school because they will be in school for about 8 hours or more. In implementing full-day school, it should be done with various activities that take place actively, creatively and fun. The full-day school system is more possible for the realization of the effectiveness of the learning process and improving the quality of learning (Hasan, 2006; Astuti, 2013; Sutarmin, 2014).

\subsection{The program of implementing the full day school to form the character of environment care}

The implementation of full-day schools in several schools is carried out with additional activities that are deliberately designed to fill school hours after teaching and learning activities are carried out. In SMPN 1 Pangka Raya, the program was carried out with several activities, namely co-curricular activities: each class has work (making light trees from the waste, light trees from corn husks). These activities are included in the subjects of crafts, flag ceremonies, literary movements: there are students' literacy data, in the literacy movement the principle directs the activities carried out in the literacy activities. The literacy movement can be done by making posters, sticking formulas in classrooms, installing the waste that has become handicrafts in classrooms. There is a green school program (green constitution), DLH Excellent achievement, leaving students on time implicitly in the classroom and outside the classroom, the teacher supervises on time habits, Friday prayers (Duha), worship, teachers also have worshipped every month, namely routine recitation in each class.

The full-day school is applied through extracurricular activities namely in the field of nineteen extracurricular activities such as basketball, volleyball, futsal, silat, karate, table tennis, badminton, flag raisers, teen red cross, scout, choir, drum band, Christianity, Mathematics, Science, English, painting, local dance, Islamic religion (habsy, tilawah, BTQ). In the classroom, there is also a picket schedule that has been agreed by all students to be carried out and if they are violated, penalties are given.

At SMP IT Hasanka, the process of using recycled paper is one of the first steps for the school to reduce environmental pollution because every time we print, we use used paper, and from now on there has been the use of plastic waste in recycling. Every month, we hold an award or reward for the cleanest class as an appreciation and enthusiasm for the class to maintain environmental cleanliness and care, as well as through extracurricular activities that develop students' interests. To face these obstacles, we hold an environmental care activity every Saturday, for the next morning we hold gymnastics clean up then clean the gutters. We watch them clean the trash in the gutter. If there are students who violate the school rules of cleanliness and the others, we solve it through the 
homeroom teacher first, then the teacher will follow it up with the student and if it is still unable to be solved, then we call the parents.

At SMP Golden Christian School, the school has activities that students must follow. These activities have been discussed in a parenting meeting before starting in the new semester such as assembly, retreat to the beach, natural parks, arboretum, outbound/field trip, Balanga museum, and Taman Wisata. Those activities aim to foster recognition and awareness of the natural environment. The development of school learning processes must be adapted to the material taught in the classroom and related to the methods and facilities and infrastructure provided by the school. While in the school environment, the hydroponic parks are made required by SMP GCS to take care of and care for them. What is planted is a plant for family medicine. The school made pickets to water, cut dead leaves, and clean the environment around the park. In the classroom, there is a picket schedule as well that has been agreed by all students to be carried out and if violated, sanctions are given.

In SMPN 2 Palangka Raya, we conduct the program activities of worship to increase faith and piety; various extracurricular programs, which include more or less extracurricular activities related to sports, spirituality, arts, and other educational fields such as science, English language club besides activities carried out by students, namely the existence of a Friday cleaning program, and cooperation in school hygiene. In the classroom, there is a picket schedule that has been agreed by all students to be carried out and if violated, penalties are given

The full-day school program implemented in all schools which are research sites already have programs in strengthening the character of caring for students' environment, for example in terms of (1) always maintain the flexibility of the surrounding environment, (2) do not take, cut or revoke growth plants found in schools, (3) do not scribble, write inscriptions on trees, stones, school walls, (4) always throw trash in place, (5) do not burn rubbish around the housing, (6) carry out environmental cleaning activities, (7) collect used goods, and (8) clean up the trash that clogs waterways. for example, there are class picket programs, trash movements, jumsih (Friday cleaning), hydroponic gardening, outbound to introduce the environment to students, problem-solving rubbish waste for students' creative crafts and creations, reduction in the use of plastic rubbish, and a class cleanliness competition $n$ encourage to have a clean soul and care for the environment of its class. As some of the results of the following interviews explain that there are obstacles in instilling the character of caring for the environment in schools that have implemented full school. Students are given an understanding and accustomed to daily activities to love the environment, for example, there is a school picket program, the movement of watering and caring for plants, making crafts from garbage waste, and the habit of getting used to throwing trash in its place. Usually, on Friday we held gymnastics together, and voluntary work, such as cleaning the TOGA garden (a family medicinal plant), tidying and cleaning the room, tidying bookshelves, etc. (Nenggala, 2007; Taufik, M. 2014; Astuti, 2013; Sutarmin, 2014).

\subsection{Students' readiness in implementing full day school programs to form the character of environment care}

All students agreed with the implementation of FDS in SMP 1 Palangka Raya. They are happy to water every day, there is a duty picket schedule and at the same time the task of watering. In the classroom, some plants are brought by students who must be cared for by each of them. They may not eat in class, and avoid the use of single-use plastics. Students feel happy with full-day school because the teachers also directed and helped flush and clean as well as with some friends who were in picket turns. Every Saturday there is joint community service guided by the clerics. The way they never taught us roughly but more towards inviting gently and never using violence or to hit. They like to water the plants in front of the class. they are taught to help and love the environment as fellow living creatures.

Students feel happy because they have to run a program that has been run by the school can interact longer with their friends at school and can do many positive activities at school. But for school activities that strengthen the character of caring for the environment in general students feel 
happy if they have to be involved in watering plants, caring for shared hygiene, with examples given by their teachers. Many parents agree with the implementation of full-day school because it can increase the foundation of their character, especially religious characters and social attitudes. The effectiveness of the full-day school in strengthening the character of environmental care is through the habit of clean living in the school environment and at home, as well as an understanding of the habit of littering, taking care, and loving plants for their living environment (Hasan, 2006; Nenggala, 2007; Taufik, M. 2014; Astuti, 2013; Sutarmin, 2014).

\section{CONCLUSIONS}

Based on research data, several conclusions in this study are: (1) readiness of school facilities and infrastructure implemented by full-day schools is adequate such as classrooms, parking lots, sports facilities, worship facilities, student playgrounds, school gardens or parks, a canteen that is sufficient to provide students with foods, will provide space and support feeling of comfort as long as students carry out full-day school activities in their school because they will be at school for about 8 hours or more; (2) school programs to strengthen students' environmental care character have not involved all elements of students and are simultaneously accustomed to the continual habits of VII to XII graders in high school; (3) the implementation of full-day school has students feel happy because they have to be involved in watering plants, caring for their hygiene, with examples which were given by their teachers. Many parents agree to the implementation of full-day school because it can increase the foundation of the children's character, especially religious characters and social attitudes. The effectiveness of the full-day school in strengthening the character of environmental love is through the habit of living clean in the school environment and at home, as well as an understanding of the habit of littering, taking care, and loving plants for their living environment.

\section{REFERENCES}

Alhamuddin. \& Buchori. 2016. The effect of multiple intelligence-based instruction on critical thinking of full day islamic elementary school students. Journal of Islamic Education Ta'dib 21(1): 31-40.

Andikurrahman. 2012. Dampak pelaksanaan full day school terhadap perkembangan sosial peserta didik (Studi kasus di SD Plus Nurul Hikmah Pamekasan). Pamekasan: Department of Tarbiyah, Islamic Religion Study Program STAIN Pamekasan.

Ansari, M.I. 2015. Strategi sistem full day school dalam membentuk empati siswa. Journal Madrasah Ibtidaiyah Muallimuna 1(1): 70-78.

Astuti, M. 2013. Implementasi program full day school sebagai usaha mendorong perkembangan sosial peserta didikTK Unggulan Al-Ya'lu Kota Malang. Jurnal Kebijakan dan Pengembangan Pendidikan 1(2): 133-140.

Hasan, N. 2006. Fullday school (model alternatif pembelajaran bahasa asing). Jurnal Pendidikan Islam Tadris 1(1): 23-31.

Islamika, D. 2011. Pengaruh full day school terhadap kecerdasan sosial anak kelas IV di SDIT Bina Anak Sholeh Yogyakarta. (Unpublished Thesis). Yogyakarta: UIN Sunan Kalijaga Yogyakarta.

Ma'ruf, A. 2016. Implementasi full day school dalam membentuk akhlak siswa di SMP Ta 'mirul Islam Surakarta tahun pelajaran 2015/2016. (Unpublished Thesis). Surakarta: University of Muhammadiyah Surakarta.

Nenggala, A.K. 2007. Pendidikan jasmani, olahraga, dan kesehatan. Bandung: Grafindo Media Pratama Publisher.

Nurhayati, I. 2014. Penerapan sistem pembelajaran 'fun \& full day school' untuk meningkatkan religiusitas peserta didik di SDIT Al-Islam Kudus. Jurnal Teknologi Pendidikan dan Pembelajaran, 2(2): 232-244.

Sutarmin, S. et al. 2014. Penanaman nilai-nilai dasar humanis religius anak usia dini keluarga perkotaan di TK islam terpadu. Jurnal Pembangunan Pendidikan Fondasi dan Aplikasi 1(2): 156-166.

Suparwadi, E. et al. 2013. Analisis dampak peningkatan jumlah penduduk dalam pola perilaku pengelolaan sampah di Kota Palangka Raya. Joined research with BKKBN Provinsi Kalimantan Tengah.

Taufik, M. et al. 2014. Pengembangan media pembelajaran ipa terpadu berkarakter peduli lingkungan tema 'konservasi' berpendekatan science-edutainment. Jurnal Pendidikan IPA Indonesia 3(2): 140-145. 